\title{
Russian historiosophy of the 18th century as a theoretical, historical and literary problem
}

\author{
Alexej Petrov ${ }^{1}$, Aleksandr Soldatchenko ${ }^{1}$, and Anna Butova ${ }^{1, *}$ \\ ${ }^{1}$ Nosov Magnitogorsk State Technical University, 455000, 38 Lenin str., Magnitogorsk, Russia
}

\begin{abstract}
It seems that the task of comprehending the past was set before the humans as soon as they separated out from the nature or (if you support an alternative point of view on human genesis) were created. It is necessary to understand how the human race had to comprehend the specific historical way of their earthy existence, which was gradually developing along with the formation of society. The authors emphasise that the object of historiosophy is dual. Modern scholars even talk about "splitting the internal range of problems of philosophy of history" into "an explanatory theory of historical "being" and an axiological interpretation of the "sense" of history", which have little in common [1]. In fact, the problem of its sense can be a pseudoproblem for those, who claim to explain a historical process ("facts"). The main conclusions and results of the research can be used in lecture and special courses in history, philosophy, and Russian literature of the 18th century.
\end{abstract}

\section{Methods}

The method of historicism and its concrete incarnations and projections in the humanities is the main focus of the paper, namely the historical-genetic, comparative-historical, historical-functional, historical-literary, historical-cultural methods. The analysis of theoretical concepts required the use of theoretical-literary, typological, and comparativestructural methods.

Fundamental propositions expressed in the works of foreign and domestic researchers of historicism E. Troeltsch, O. G. Oexle, K. Jaspers, N. Kareev, T.V. Artem'eva, I. M. Savel'eva, A.V Poletaev et al. comprise the methodological basis of the research.

\section{Introduction}

At the turn of the 19th-20th centuries, in his article written for the Brokgaus and Efron Encyclopedia, N. I. Kareev pointed out the identity ("equivalence") of the terms "philosophy of history" and "historiosophy". He also noted that the latter term "did not take root in the Russian language" [2]. We also learn from this article that V. Cieszkowski was, obviously, the first who used the word "historiosophy" as a term in his work "Prolegomena zur Historiosophie" in 1838 [3]. It should be noted that the term "philosophy of history"

* Corresponding author: annb.79@mail.ru 
was introduced by François Marie Arouet Voltaire in the introduction to "Essai sur les mœurs et l'esprit des nations" ("Essay on Universal History, the Manners, and Spirit of Nations") in 1756.

Modern scholars do not make a strict differentiation between the terms "historiosophy" and "philosophy of history" $[5,6,7,8]$. Though the differentiation between historiosophy, philosophy of history, cultural history, metaphysics of history, historiology, etc. is suggested by some researchers $[1,6,8,9,10]$. They believe that it is theoretically justified, because these terms appeared at different time, they have different subjects, and imply different ways of comprehending the history of philosophical forms, i.e. this differentiation can hardly be put into practice. According to the current tradition in humanitaristics and, in particular, in the study of literature, the term "historiosophy" is considered the most preferable. Here a hidden desire to separate philosophy of history as a politicized and ideologized doctrine, which it used to be in the USSR till the 1990s, from historiosophy in the interpretation, which was popular 10-20 years ago. This interpretation can trace its origins back to Russian religious philosophers, who lived at the end of the 19th till the first third of the 20th century.

The object of historiosophy was scientifically defined not so long ago, in the 18th century (and in the 19th century in Russia), when, as most researchers think, history and philosophy began to develop as scientific disciplines. Prescientific period of historiosophical knowledge lasted for thousands of years. For example, J. I. Semenov believes that the first historiosophical doctrine, which is known to us, was developed by an Egyptian Pharaoh Amenhotep IV, who lived in the XIVth century B.C. [6]. The same researcher ascribes the first historiosophical concept (of the world history) to St. Augustine Aurelius (the 5th century). This concept is known as providential. Besides doctrines and concepts, historiosophical knowledge took and is still taking the form of ideas and notions, which can be found in different archaic myths (cosmogonical, calendar, aetiological, heroic, etc.), as well as in modern mythologies.

\section{Thoughts on laws and sense of history}

Clarification of "an explanatory theory of historical "being" component of the object of historiosophy (laws of history) allows us to point out general notions "at a medium level". They are unity (wholeness); motive forces; direction; aim; values; periodization of a historical process. They, in their turn, are concretized by the notions "of the third level". Such notions as causality, determinism, predetermination and indeterminateness, fortuity and necessity, opportunity and reality, alternativeness, freedom and need, the role of a personality and masses, progress and regress, linearity and cyclicity should be mentioned here. These terms will be used in the monograph in their conventional - dictionary meaning.

The second component of the object of historiosophy is the sense of history. Here opposing points of view, firstly, on the very possibility of posing this problem in philosophy and historical science, secondly, on the means and boundaries of comprehending this sense continue to exist. J. V. Petrov thoroughly studied this problem [1]. He brings all diverse opinions on the problem, which were formed during more than three centuries, to three main positions.

The first one is "historical objectivism". It is based on a classical contraposition of a thinking subject to a cognizable object. History as an object already possesses some senses. So the subject's task is to extract these senses from history. The thinkers of the XVIIthXVIIIth century held this viewpoint and it sporadically revived in the XIXth-XXth century (Hegel, Marx and their followers). 
The second one is "historical subjectivism". It was substantiated by Immanuel Kant. From his perspective aims and senses do not belong to a historical process, that is why they cannot be cognized by scientific and theoretical means. They are only rethought by people so that they can be applied to history.

The third one is represented by "philosophy of life" in the XIXth century and by existential and hermeneutical philosophical traditions in the XXth century. Historical life (people as thinking, conscious beings and everything produced by them, including senses and meanings) interprets and comprehends itself. In this case historical past appears as "a world of semantic relations which is open to diverse interpretations"; and a sense of history is understood as constructed inside history by history (its participants and the life "they live") and as historical (non-universal). The notion of historical project is substantiated within the framework of this paradigm. It means a person and humankind, who form and perform themselves in historical reality. The above-mentioned position has its limitations. The most important one is that historical life (being, reality) should not and cannot be reduced to its senses and being itself is meaningful.

We believe that the question of a sense of history cannot be scientifically proved. It is a speculative question. It is mainly a question of faith and a personal spiritual search for those who are not philosophers. Fiction writers and their characters often demonstrate such attitude to this question. It means that experts in literature as a rule deal with this statement of question.

We consider it necessary to explain the meaning of the expression "a sense of history". One might say that to find a sense in history is to explain it, substantiate it on reasonable ground. Partially this question overlaps the question (and the answer to it) of meaning of human life. Yet it cannot be reduced to it. There are not so many ways of rationalising (giving sense to) a historical process. Practically all of them were mentioned before and stand behind the notions of "a medium level": 1) to prove that a historical process has unity and wholeness; 2) to find out its motive forces; 3) to determine its aim and as a consequence, 4) axiological attitude to it; 5) to specify its direction; 6) divide it into periods.

The sought-for sense can be found both in history itself and outside history. There are many compromise variants too.

In the first case a sense of history is connected with a person/humankind as "a historical project" and with "historical formations" (everything that was created in the course of history and remains in it). In general these senses are: 1) realisation of his/her nature and its opportunities by a person and, in a radial case, transcending its limitations (self-perfection; cognition and mastery of the world around, etc.); 2) achievement of ideals by humankind, first of all, a perfect social order and the so-called "fullness of being".

In the second case we deal with the Absolute of any kind beyond earthly history (God, Absolute Idea, Sophia, Cosmic Mind, etc.). Providential concepts, which go back to biblical historiosophy, are the most long-standing.

\section{Becoming of Scientific historiosophy}

In Russia historiosophical thought like all forms of philosophizing, scientific research and artistic creative work in early Rus was based on religious (Christian) Weltanschauung until the $18^{\text {th }}$ century (approximately - the Age of the Enlightenment). Several ideologemes and concepts, in which biblical historiosophemes combined with topical political ideas: the origin of Russia and authorities in Russia; Divine Chosenness of the Russian people; the Russians as a new people; a theory of Divine Punishment; "Moscow is the Third Rome"; the struggle between good and evil in history, etc., formed within the framework of Old 
Russian historiosophy $\left(10^{\text {th }}-17^{\text {th }}\right.$ century). Corresponding notions passed into historiosophical constructs of the New Age, taking sometimes the most unexpected forms.

In the $18^{\text {th }}$ century historiosophy became scientific, although philosophical and historical works were written in Russia only in the 19th century. Like other spheres of knowledge historiosophy began to use rational methods of natural and exact sciences. Together with other sciences it gradually removed all extra, improper forces, all supernatural from history. In general historiosophy of the Enlightenment was deistic. In the 18th century "historiosophy of the world", which was characteristic for the Middle Ages, finally transformed to "historiosophy of a society". The researchers trace its genesis back to the beginning of the New Age (Niccolò di Bernardo dei Machiavelli, Francis Bacon, 1st Viscount St Alban) [8]. Giving up theological explanation of the course of history, the enlighteners began to think about "natural" reasons for social and historical activity of people and a historical process. Those reasons were "the laws of nature" (which were also the laws of good sense, natural laws, and the laws of history) and "human nature".

The enlighteners had hopes for the future (though there were pessimistic predictions, for example, Jean-Jacques Rousseau), because they thought that the ideal of a human and a society was feasible and could be quickly achieved in reality. Perfection, i.e. a gradual development through upbringing, education, training, reformation of social institutions (especially legislation), which were still unreasonably organised, and human nature distorted by passions (or original sin), was often viewed as an instrument for transformation. Hence a large number of utopian projects appeared. They were not just brought to life by the Enlightenment but actively put into practice. It is notable that many utopian ideas were at the same time historiosophical, components of "historiosophy of society" of the $18^{\text {th }}$ century ("social contract", "enlightened absolutism", "progress of the human mind").

Positive (mainly) axiological perception of the future was opposed by (mainly) negative attitude of the enlighteners to the present, where they certainly did not see desirable perfection. (For now we shall ignore official political discourse, which aim is to confirm the existence of an ideal in the present.) Criticism of the present was an important part of the activity of the enlighteners, but that critical, satirical and destructive approach had little to do with historiosophy. To tell the truth, the enlighteners criticised (denounced) the past not with the purpose of scientific cognition but in order to learn certain moral lessons - both positive and negative - of "political" behaviour (i.e. behaviour in society) from it. 18thcentury Russian historical writers (Tatishchev, Lomonosov, Catherine II, Emin, Bolotin, Shcherbatov, Karamzin, et al.) clearly expressed such attitude to the past. Historiosophical ideas were theoretically expressed mainly within the framework of historical writing.

\section{Conclusion}

The scientific historiosophical thought of the 18th century was generalising. It was important for a philosophizing historian to discover a single whole, a general principle, a universal law, governing people and their actions and, therefore, history, rather than the differences between different historical epochs and different peoples [11, 12]. At the same time, individualising tendencies were appearing in the shadow of that predominant cognitive mainstream in the form of problems and questions, which would be solved in the 19th century. From their very beginning ("Synopsis" by Innocent Gizel, the beginning of the 1670s), Russian historical writing and historiosophy formed as "country", nationally oriented. Numerous historical writers of the 18th century created "Russian histories", which were as famous and noteworthy as the European ones. The 18th-century philosophy and historical science developed some particular theories with historiosophical orientation and some notions with historiosophical substratum: "Norman theory", "Novgorod liberty", 
"Varangian-Russians", "public morals and manners", "national character", "nativelandness", "Russian god", "ancient" and "modern" Russia, etc.

The problems of national identity were determinative for the 19th-century historiosophical thought. As a result, new historiosophemes appeared ("Russian idea", "Russian soul", "Russian way", etc.) [12].

It is the interest of Russian historiosophy - from Nestor to N. A. Berdyaev (who is usually the last one to be mentioned in corresponding essays and textbooks) - in the questions of national identity, a "special" way of Russia that is recognised by the researchers as its special feature. Such question as "Who are we?", "Where are we from?", "Where are we going?" are considered to be the contents of Russian historiosophical reflection.

\section{References}

1. Ju. V. Perov, Historicity and Historical Reality (St. Petersburg, 2000)

2. N. Kareev, Philosophy of History in Russian Literature (Moscow, 2015)

3. A. Cleszkowski, Prolegomena zur Historiosophie (Berlin, 1838)

4. T. V. Artem'eva, From Glorious Past to Better Tomorrow: History Philosophy and Utopia in Russia of the Age of Enlightenment (St. Petersburg, 2005)

5. T. V. Artem'eva, Russian Historiosophy of the $18^{\text {th }}$ Century (St. Petersburg, 1996)

6. Ju. I. Semenov, Philosophy History. (General Theory, Basic Problems, Ideas and Concepts from Ancient Times to Present Day) (Moscow, 2003)

7. R. Ja. Podol', Theory of Historical Process in Russian Historiosophy in 1920s - mid1930s (Moscow, 2009)

8. I. M. Savel'eva, A.V.Poletaev, History and Time. Remembrance of Past (Moscow, 1997)

9. L. I. Novikova, I.N. Sizemskaja, Russian Philosophy History: Series of Lectures (Moscow, 1997)

10. A. V. Malinov, Philosophy History in Russia in the $18^{\text {th }}$ Century (St. Petersburg, 2003)

11. M. A. Barg, Epochs and Ideas: Historicism Establishment (Moscow, 1987)

12. Ju. V. Stennik, Idea of "Ancient" and "New" Russia in Literature and Social and Historical Thoughts of the $18^{\text {th }}$ to early 19th Centuries (St. Petersburg, 2004)

13. Ju. V. Stennik, Historiosophical Aspects of Contents of Russian Dramaturgy of the 18th Century (Genre of Tragedy). Sb. 19 (St. Petersburg, 1995) 